\title{
Macroeconomic Differences in Public and Private Union Density: An Analysis of U.S. State Economies
}

\author{
Louis J. Pantuosco, Darrell Parker, William Seyfried, and \\ Scott Lyman*
}

\begin{abstract}
In this paper, we investigate the macroeconomic impact on U.S. state economies of differences in the percent of the employed in private sector unions and the percent of the employed in public sector unions. Using annual data from 1983 through 1996 for the 48 contiguous U.S. states, we search for contrasting impacts of private and public sector union density on state economic conditions. Four individual equations are estimated, one for each economic measure: state unemployment rates, wage inflation, productivity growth, and GSP growth. Then, tests are conducted to determine the relative difference between private and public unions. Using a fixed effects model, in each equation we find significant differences between the effects of public and private union density on labor markets and economic growth. We conclude that disaggregating union data provides some insights toward the future as public unions expand to represent a larger percentage of total union membership.
\end{abstract}

\section{INTRODUCTION}

Over the past 25 years, there has been a growing disparity between the percentage of the workers unionized in the private sector and the percentage of workers unionized in the public sector. While private sector workers have experienced a variety of obstacles that decreased the power of unions and the incentive of workers to organize, public sector workers have witnessed conditions that uphold and even inspire union membership. In this paper, we investigate the macroeconomic impact of differences in the percent of the employed in private sector unions (private sector union density) and the percent of the employed in public sector unions (public sector union density) on U.S. state economies. We search for contrasting impacts of private and public sector union density on state economic conditions, such as wages, growth, and unemployment.

Over the sample period of 1983 to 1996, the empirical data in U.S. states indicates that the unionized percentage of the employed in the private sector and the unionized percentage of the employed in the public sector have followed two distinct paths. Figure 1 displays the national trend over the past 25 years. While the percent unionized in the private sector has declined, the percent unionized in the public sector has leveled off. This chart simply exposes the tip of the differences that exist between private and public sector unions. Beneath the surface,

"Pantuosco, Seyfried, and Lyman are from the Department of Economics, Winthrop University, Rock Hill, SC; Parker is from the Department of Economics, Georgia Southern University, Statesboro, GA. 
there are disparities between states and within states over time. In 1996, private sector union density ranged from 18.3 percent in Michigan to 2.6 percent in the Carolinas (see Figure 2). ${ }^{1}$ In the same year, public sector union density ranged from 73 percent in New York to 3.7 percent in South Carolina (see Figure 3). Clearly, there is greater disparity between states in the public sector. The decline in private sector unions combined with the growth in public sector unions caused public unions to gain in the percentage of overall union membership, but approximately two-thirds of all union members are still in the private sector. The underlying data also indicate that private sector and public sector union membership within the individual states have yielded different trends. Table 1 shows the change in union density by state over the sample period. In the private sector, every state experienced a decrease in the percentage of union density. West Virginia experienced the largest change in private sector union density, which declined from 26.1 percent of the employed to 13.9 percent. On the other hand, nearly half of the U.S. states witnessed increases in their public sector union density: Nevada had a 12.2 percentage point increase.

FIGURE 1

Public and Private Union Density

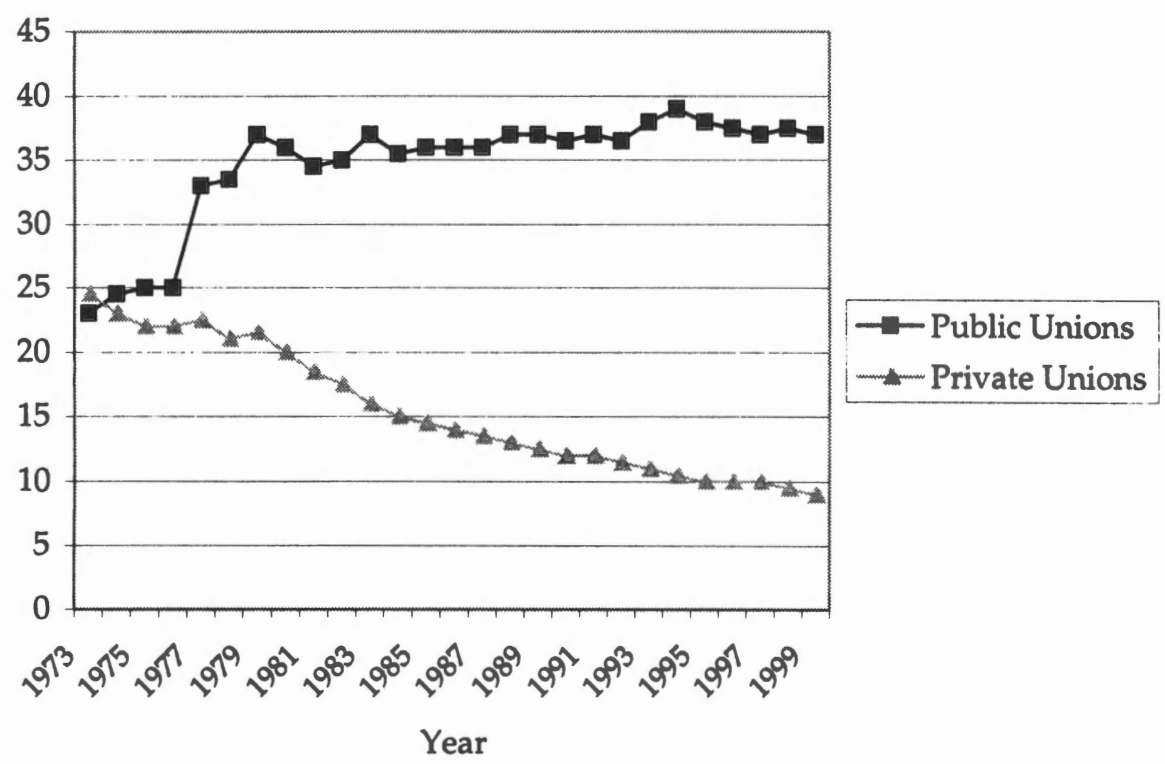

${ }^{1}$ States with comparable levels of union density are grouped together for graph clarity in Figure 2 and Figure 3. 


\section{FIGURE 2}

Private Unions

1996

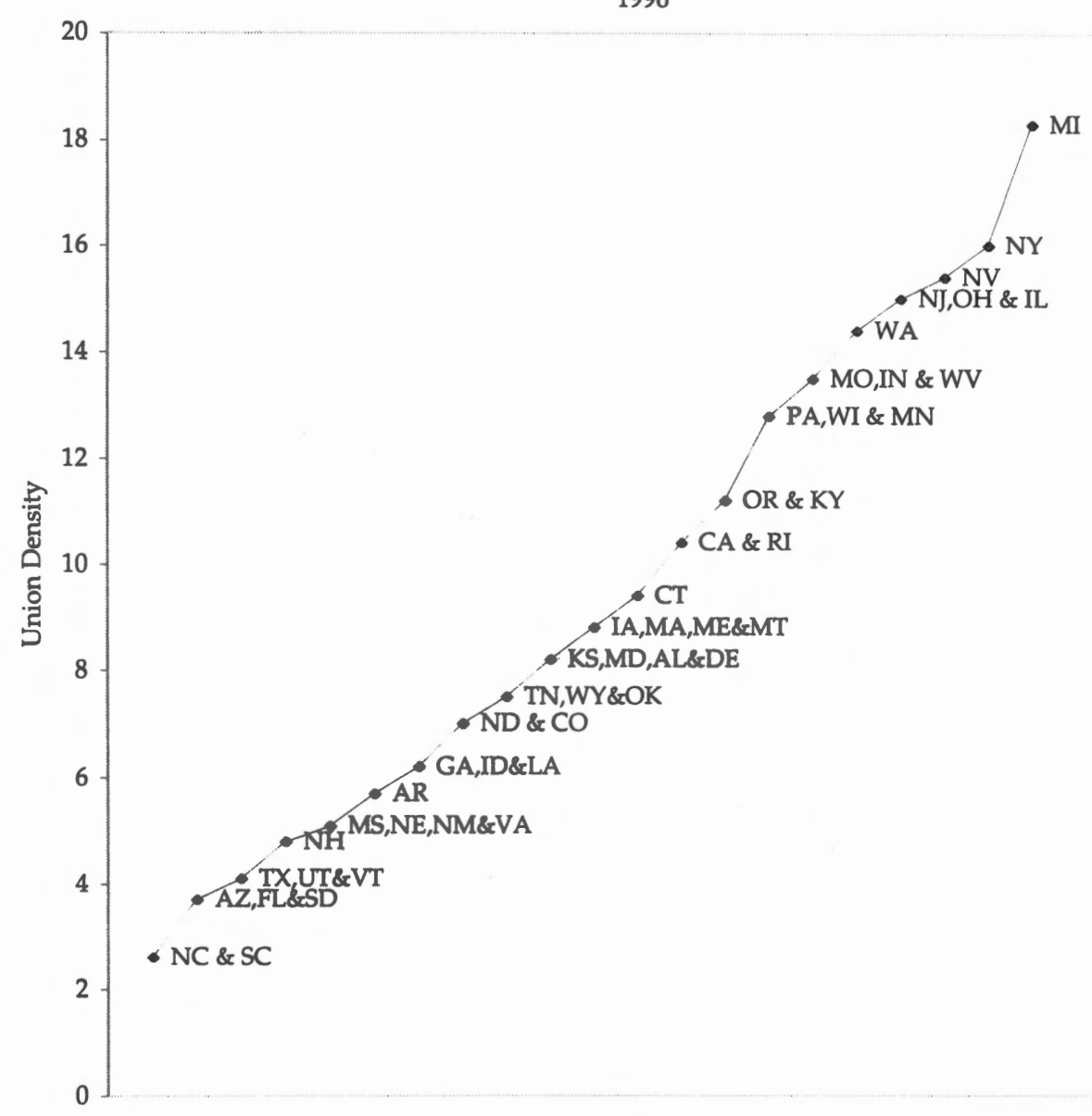

States 
FIGURE 3

Public Unions

1996

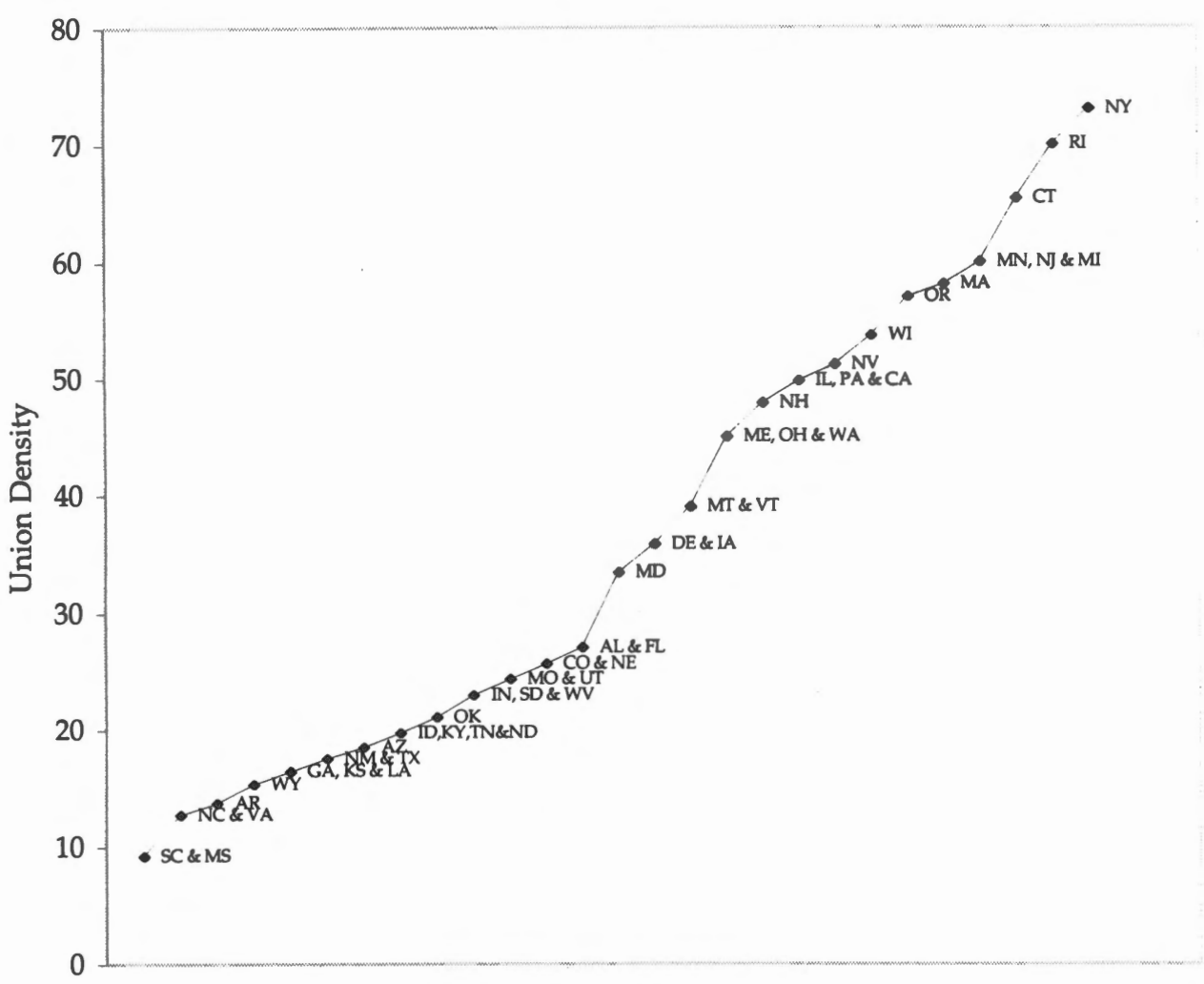

States

These trends result from at least four differences between public and private sector unions. First, public sector unions operate in a noncompetitive environment. Second, public sector unions are nonprofit institutions. Third, the laws governing public sector unions and collective bargaining differ by state. Fourth, the laws governing the individual workers are more accommodating in the private sector, where workplace lawsuits reduce the need for union representation.

The reactions of state governments, workers, and unions to structural differences in the labor market, federal laws, and bargaining agreements lead to different managerial objectives, power, and motivations (Freeman 1988). As a result, union density in the public sector can have a different impact on economic performance than union density in the private sector. Our emphasis is not on the cause of private and public sector union disparity, but on the effect. 
TABLE 1

Change in Union Density From 1983 to 1996

\begin{tabular}{|c|c|c|c|}
\hline State & $\begin{array}{c}\text { Private Sector } \\
\text { Change }\end{array}$ & State & $\begin{array}{l}\text { Public Sector } \\
\text { Change }\end{array}$ \\
\hline WV & -12.2 & TN & -8.8 \\
\hline IN & -11.2 & $\mathrm{AZ}$ & -7.7 \\
\hline $\mathrm{PA}$ & -10.4 & $W Y$ & -7.7 \\
\hline MA & -8.6 & LA & -6.8 \\
\hline MO & -8 & ND & -6 \\
\hline NY & -8 & $\mathrm{DE}$ & -5.8 \\
\hline WA & -7.6 & UT & -5.7 \\
\hline $\mathrm{DE}$ & -7.5 & $\mathrm{ME}$ & -5.3 \\
\hline $\mathrm{OH}$ & -7.4 & NC & -5.3 \\
\hline CA & -7.3 & VT & -5.3 \\
\hline $\mathrm{CT}$ & -7.3 & SC & -5.1 \\
\hline UT & -7.2 & MS & -3.9 \\
\hline $\mathrm{AL}$ & -7 & VA & -3.8 \\
\hline MI & -7 & NE & -3.7 \\
\hline WI & -7 & $\mathrm{KS}$ & -3.6 \\
\hline KY & -6.9 & MA & -2.3 \\
\hline MD & -6.2 & WA & -2.1 \\
\hline IL & -6.1 & ID & -1.6 \\
\hline NJ & -6.1 & IN & -1.6 \\
\hline IA & -5.8 & PA & -1.4 \\
\hline MT & -5.7 & $\mathrm{TX}$ & -0.7 \\
\hline OR & -5.2 & OK & -0.7 \\
\hline GA & -5.1 & $\mathrm{AR}$ & -0.6 \\
\hline ME & -5.1 & $\mathrm{FL}$ & -0.3 \\
\hline $\mathrm{AZ}$ & -4.9 & SD & 0.5 \\
\hline LA & -4.9 & GA & 1 \\
\hline $\mathrm{TN}$ & -4.9 & $\mathrm{CO}$ & 1.1 \\
\hline VA & -4.9 & WV & 1.5 \\
\hline NM & -4.8 & NM & 1.9 \\
\hline $\mathrm{NE}$ & -4.6 & RI & 1.9 \\
\hline $\mathrm{AR}$ & -4.5 & KY & 2.5 \\
\hline $\mathrm{CO}$ & -4.2 & $\mathrm{CT}$ & 2.5 \\
\hline ID & -4.2 & MD & 3.5 \\
\hline KS & -4.2 & $\mathrm{AL}$ & 3.6 \\
\hline $\mathrm{MN}$ & -4.2 & $\mathrm{NY}$ & 3.7 \\
\hline SD & -4.2 & MI & 4.7 \\
\hline TX & -4 & NJ & 5.3 \\
\hline MS & -3.9 & $\mathrm{OH}$ & 6.2 \\
\hline NV & -3.8 & $\mathrm{MO}$ & 6.7 \\
\hline FL & -3.3 & $\mathrm{CA}$ & 6.9 \\
\hline RI & -3.2 & $\mathrm{MN}$ & 8.6 \\
\hline ND & -2.9 & MT & 8.9 \\
\hline NC & -2.8 & WI & 9.1 \\
\hline $\mathrm{NH}$ & -2.7 & IA & 9.4 \\
\hline VT & -2.3 & OR & 10.7 \\
\hline OK & -1.3 & IL & 11.4 \\
\hline $\mathrm{SC}$ & -1.3 & $\mathrm{NH}$ & 12.1 \\
\hline$W Y$ & -2.8 & NV & 12.2 \\
\hline
\end{tabular}

In this paper, we address questions that are specific to public unions and private unions. For example, how do public and private sector unions impact U.S. state economic activity? Specifically, what are their effects on state unemployment rates, wage inflation, productivity growth, and gross state product (GSP) growth? 
Are there significant differences between the effects of public sector and private sector unions on the economy? Should state governments modify policies regarding public unions in an effort to fine-tune their economic objectives?

We address these questions using annual data from 1983 through 1996 for the 48 contiguous U.S. states. We estimate four individual equations to assess the impact of public and private sector union density on four economic measures: state unemployment rates, wage inflation, productivity growth, and GSP growth. The model is then re-estimated using a fixed effects approach that captures state differences in the effects of public and private unions on the four economic measures. Then, we use the appropriate test to determine the relative difference between private and public unions.

\section{METHODOLOGY}

The objective of the analysis is to investigate the impact of private and public sector unions on four macroeconomic barometers between and within states over time. With this in mind, a panel is used to capture the cross-sectional and time-series components of the data. As with any estimation technique, a panel model is subject to the econometric concerns of multicollinearity, heteroscedasticity, and autocorrelation. These issues are addressed using the following approaches: 1) a parsimonious model was used to reduce the opportunities for multicollinearity; 2) rates of change were incorporated to mitigate heteroscedasticity and autocorrelation; and 3) lagged variables were added to control for autocorrelation and to provide a test for persistence.

Each of the four equations contains a constant term, a measure of public sector union density, a measure of private sector union density, and other economic variables helpful in explaining the behavior of the respective dependent variable. $^{2}$ Another econometric issue exposed by panel data is whether the model contains "fixed" or "random" effects. Since the data make use of all states in the continental U.S. rather than a sample of a larger population, the fixed effects model is appropriate (Kennedy 1998). Due to potential differences between states and over time, it may be necessary to introduce N-1 state dummies and T-1 time dummies. The fixed effects model econometrically accounts for these differences by making use of computational short cuts without incurring a loss in the number of observations.

Due to potential endogeneity of right-hand-side variables in three of the equations, two-stage least squares was employed in their estimation. Each equation was estimated with and without fixed effects. The significance of the fixed effects components in the respective equations suggests that it is the preferred approach. In each case, tests were conducted to assess whether there were significant differences between the effect of public and private unionization.

\footnotetext{
2Each of the variables is defined in the Data Sources section of the Appendix.
} 


\section{MODEL AND EMPIRICAL RESULTS}

\section{Public and Private Unions in the Labor Market}

The first equation addresses the determination of state unemployment rates:

$$
\begin{aligned}
& \text { UR }=a_{0}+a_{1}{ }^{*} \text { PUBUNION }+a_{2}{ }^{*} \text { PRIUNION }+a_{3}{ }^{*} \text { WAGINF }+a_{4}{ }^{*} \text { GSP }+ \\
& a_{5}{ }^{*} \text { LAGUR }+a_{6}{ }^{*} \text { MANEMP }+e,
\end{aligned}
$$

where UR is the unemployment rate; PUBUNION is the percentage of public sector workers unionized; PRIUNION is the percent of private sector workers unionized; WAGINF is the rate of wage inflation; GSP is the growth rate of the GSP; LAGUR is the lagged unemployment rate; MANEMP is the percentage of the employed working in the manufacturing sector; and e is the error term. All data are annual by state.

Many researchers have highlighted the adverse effects of unions on unemployment rates. In a survey of U.S. states, Summers (1986, p. 376) claimed that "a significant part of the observed increase in normal unemployment in recent years may be attributed to the effects of unions." Lindbeck and Snower (1988) view union workers as insiders who decrease the opportunities of the outsiders. As a result, the job skills of outsiders deteriorate and cause them to be less employable. Other studies confirm a positive relationship between union density and unemployment rates (e.g., Layard, Nickell, and Jackman 1991; Karras and Stone 1993; Pantuosco, Parker, and Stone 2001).

The relationship between unemployment and private sector unions differs from the relationship between unemployment and public sector unions. Private sector employment is more sensitive to cyclical fluctuations than is public sector employment. In fact, contrary to private unions, public sector unions may have positive employment effects. Allen (1988, p. 272) states that "(public) unions reduce by a substantial amount the already low lay-off and unemployment probabilities in the public sector in contrast to the private sector, where rates are much higher under (private) unionism."

One explanation for the increased volatility of employment for private sector union members versus public sector union members is the occupations of public sector employees. Many public sector employees work in industries that are less cyclical. With this argument in mind, Allen (1988) finds that even after holding occupations constant, employment is more volatile in the private sector labor market than in the public sector. He concludes that public sector workers are sheltered from the competitive pressures experienced in the private sector.

Wage inflation is added to the equation to estimate the Phillips relation (Bartik 1991; Phillips 1958) while GSP growth captures state cyclical fluctuations (Topel 1986; Pantuosco and Parker 1998). In the unemployment equation, the coefficient of the lagged dependent variable estimates the speed of adjustment for 
unemployment rates. The closer this coefficient is to one, the slower the adjustment process. Manufacturing employment acts a control variable for the demand of income-sensitive goods.

The second equation estimates wage inflation in occupations covered by unemployment insurance:

$$
\begin{aligned}
& \text { WAGINF }=a_{0}+a_{1}{ }^{*} \text { PUBUNION }+a_{2}{ }^{*} \text { PRIUNION }+a_{3}{ }^{*} \text { UR } \\
& +a_{4}{ }^{*} \text { MANEMP }+e .
\end{aligned}
$$

Lewis (1990) claims that the union wage effect is positive for both private sector and public sector unions. But other research exposes some potential differences between the wage effect of public unions versus private unions. First, Freeman and Valletta (1988) state that the union wage effect generated by public sector unions has a positive impact on the wages of nonunion employees in a given economy. They explain this phenomenon by suggesting that the wage spillover effect is higher in states that encourage collective bargaining in the public sector. Further evidence provided by Zax and Ichniowski (1988) indicates that the wage benefits of organized departments spread to the unorganized departments within city government. Second, the voting power of public unions may influence politicians to support the public union's demands (see Courant, Gramlich, and Rubinfeld, 1979). Third, while private unions must be sensitive to international and domestic competition while negotiating wage increases, public unions are not subjected to external competitive pressure.

Each of these findings suggests that wage inflation may be greater in states where public employees are organized. However, other factors may mitigate this effect. In some states, public unions are not allowed to strike and wages are not an issue of contract negotiations. Also, fiscal restraints limit the governing body's ability to support a public union wage increase. Furthermore, Babcock and Engberg (1997) warn that even though unionized public sector workers are paid more than their nonunion counterparts are, it is unclear where the government finds the resources to compensate the unionized public employees. Nonunion workers may subsidize union employees.

Manufacturing employment was added to the equation to control for structural differences in state wages. Empirical data indicates that workers in the manufacturing sector are traditionally paid higher wages than those in other sectors. ${ }^{3}$ Therefore, increases in the percentage of workers in the manufacturing sector are correlated with increases in wages between and within states. The unemployment rate was included to capture the impact of exogenous shocks to the state labor market (Hyclak and Johnes 1992; Phillips 1958).

The results from our regression analysis are reported in Table 2 . The labor market panel estimation is reported for each equation and then the fixed effects model is reported. Public union membership has a significant negative effect on ${ }^{3}$ Wage and Employment data from the U.S. Department of Labor, Bureau of Labor Statistics, Employment and Wages, Annual Averages. 
the unemployment rate in the initial panel estimation. This is consistent with the employment effect found by Allen (1988). When the equation is estimated controlling for fixed effects, the impact of public unions is no longer significant. However, private union density does have a significant positive effect on the unemployment rate. These results coincide with those found for aggregate union membership by Summers (1986) and Pantuosco and Parker (1998). A chi-square test is used to estimate the difference between the coefficients for public and private unions. In the fixed effects model, there is a significant difference between the effects of public and private union membership on unemployment rates. An increase in private unionization significantly increases unemployment rates and has an impact significantly greater than that of public unions. The result that an increase in private unionism encourages job search is a distinct impact from that of public unionization.

TABLE 2

Public and Private Sector Unions in the Labor Market

(absolute t-statistics)

\begin{tabular}{lcccc}
\hline Variable & UR & UR (fixed) & Wage Inf & Wage Inf (fixed) \\
\hline Constant & $1.230^{*}$ & & $3.614^{*}$ & \\
& $(7.52)$ & & $(13.12)$ & -0.027 \\
Public union & $-0.007^{*}$ & -0.002 & $0.016^{*}$ & $(1.40)$ \\
& $(2.78)$ & $(0.21)$ & $(3.79)$ & 0.060 \\
Private union & 0.008 & $0.106^{*}$ & 0.011 & $(1.18)$ \\
& $(0.97)$ & $(3.85)$ & $(0.71)$ & $-0.379^{*}$ \\
UR & & & $-0.245^{*}$ & $(7.26)$ \\
& & & $(6.81)$ & \\
UR(-1) & $0.806^{*}$ & $0.691^{*}$ & & \\
Wage Inflation & $(45.60)$ & $(27.96)$ & & \\
GSP growth & $0.185^{*}$ & $0.172^{*}$ & & \\
\%Manufacturing & $(6.44)$ & $(5.10)$ & & $(3.89)$ \\
Public-Private Union & $-0.176^{*}$ & $-0.161^{*}$ & & -0.087 \\
$\chi^{2}$ & $(13.80)$ & $(11.25)$ & & \\
\hline
\end{tabular}

***indicates significance at the $10 \%$ level.

** indicates significance at the $5 \%$ level.

* indicates significance at the $1 \%$ level

The coefficients on both public and private unions display a positive sign in the initial wage inflation estimation; however, only public unions are significantly correlated with wage inflation. When fixed effects are considered, a different pattern emerges, with a negative coefficient for public unions and a positive coefficient for private unions. While neither coefficient is significantly different from zero, the difference between the public and private union coefficients is statistically significant. Thus, in the fixed effects estimation, the wage spillover effects from unionization are significantly greater for private unions than they are for public unions. 
The coefficients on manufacturing employment reveal that industry mix plays a significant role in the labor market equations. In the unemployment equation, the coefficient on manufacturing employment is negative and significant. This correlation captures the distinct effect of manufacturing's role in the employment mix on the dynamics of the labor market. A larger portion of the labor force employed in manufacturing is correlated with lower unemployment rates. The coefficient on manufacturing is positive and significant in the wage equation. The manufacturing sector is typically a higher-wage sector, and structural differences in state industry mix are reflected in the demand for labor and, hence, the wage rate. The fixed effects model shows the same correlations, but the magnitude of the impact from the manufacturing sector on wages is much greater.

As expected, the results indicate that the growth in GSP has a negative and significant impact on unemployment rates. The constant terms in both the wage inflation and unemployment equations reveal a positive core rate. In addition, the lagged coefficient of unemployment rates indicates that these rates are slow to adjust. The negative significant coefficient of the unemployment rate in the wage inflation equation can be interpreted as the slope of the classic Phillips curve. Controlling for the fixed effects model does not alter the signs and significance of these measures.

\section{Unions and Economic Growth}

The third equation estimates GSP growth:

$$
\begin{aligned}
& \text { GSP }=a_{0}+a_{1}{ }^{*} \text { PERCAPGSP }+a_{2}{ }^{*} \text { PUBUNION }+a_{3}{ }^{*} \text { PRIUNION }+ \\
& a_{4}{ }^{*} \text { MANEMP }+a_{5}{ }^{*} \text { POP }+e,
\end{aligned}
$$

where GSP is the growth rate of the GSP; PERCAPGSP is the lagged state GSP per capita; and POP is the growth rate of the population. Public sector unions have offsetting effects on state growth. On the positive side, public sector unionization coincides with more stable employment and employment growth (Allen 1988). Yet tax increases that are necessary to support the increased level of public sector employment lower GSP growth. State governments can reduce their need for tax increases if nonunion wages are reduced to offset union wage premiums. In the private sector, the evidence suggests that private unions are negatively correlated with growth. Freeman and Medoff (1984) claim that the monopoly wages obtained by unions decrease gross national product by 0.2 to 0.4 percent. Pantuosco, Parker, and Stone (2001) concluded that private unions are correlated with lower GSP growth.

The state measure of lagged per capita GSP is added to the estimation to capture the convergence effect. Due to the convergence effect, states with higher levels of GSP per capita are expected to grow at a slower rate. Conversely, those states with low per capita GSP will experience higher rates of growth (Barro and Sala-i-Martin 1991). Population growth is added to Equation 3 as a control factor, while manufacturing employment is a proxy for differences in state industrial composition. 
The fourth equation focuses on the determination of productivity growth:

$$
\begin{aligned}
& \text { PROD }=b_{0}+b_{1}{ }^{*} \text { PUBUNION }+b_{2}{ }^{*} \text { PRIUNION }+b_{3}{ }^{*} \text { PUBUNION }^{2}+ \\
& b_{4}{ }^{*} \text { PRIUNION }{ }^{2}+b_{5}{ }^{*} \text { MANEMP }+e,
\end{aligned}
$$

where PROD is the productivity growth rate; $\mathrm{PUBUNION}^{2}$ is the percent of employed workers who are public union members squared; and PRIUNION ${ }^{2}$ is the percent of employed workers who are private union members squared.

A debate continues regarding the impact of unions on productivity. Freeman and Medoff (1984) theorize that the "collective voice" of unions communicates more efficiently with management and increases the productivity of the firm. On the contrary, other researchers claim that even if unions appear more productive, productivity increases may stem from a wage effect or shock effect, or may be the result of biased surveys (see Addison and Hirsch 1989, Hirsch 1997, and Katz 1986). In fact, some industry-level studies conclude that private sector unions are correlated with decreased productivity growth (Hirsch 1991; Hirsch and Link 1984; Maki 1983).

The productivity debate becomes more complicated when unions are disaggregated to the public/private sector level. One could argue that public sector unions have more adverse effects on productivity than private sector unions. While private unions have wage effects, some public unions cannot negotiate wages. While the survival of private unions is contingent on their productivity, public unions operate in less-competitive environments. Furthermore, while some public unions are required to increase employment in an effort to provide better services for their community, private sector unions are under less political pressure to generate labor growth. ${ }^{4}$ However, many industry-level studies that focus on private sector unions determined that a negative correlation exists between unions and productivity. ${ }^{5}$ The question of the public and the private sectors' impacts on state-level productivity is unique to this study.

We test for second order effects of unionization on productivity by including the squared terms for both public and private unionization. This allows us to determine if the direction of change measured is occurring at an increasing or decreasing rate, and if any optimum level of union density may exist.

Manufacturing employment is incorporated into Equation 4 to capture the impact of cyclical demand on productivity. On one hand, technological advancements have enabled American manufacturers to remain competitive in the face of foreign competition (Krugman 2000). On the other hand, it is likely that the positive correlation between productivity and the manufacturing sector is generated from a wage effect, or survival effect (Jensen, McGuckin, and Stiroh 2001). ${ }^{6}$ Regardless of the rationale, we expect manufacturing employment to be directly related to productivity within the U.S. states.

\footnotetext{
${ }^{4}$ Teachers want to reduce class size and police want to increase the number of officers per car (Allen 1988). In these examples, productivity improvements are difficult to measure.

5 See Hirsch (1991), Hirsch and Link (1984), and Maki (1983).

6The wage effect theorizes that the higher wages prevalent in the manufacturing sector inspire higher productivity. The survival effect reasons that only the most productive firms survive.
} 
Table 3 reports the results of an analysis for the economic growth variables. Again the panel estimate is first reported followed by the estimate of the fixed effects model. In the productivity equation, the rate of public union membership is not a significant factor for economic growth. Alternatively, in the estimation of GSP growth, public unionism is weakly significant and positively correlated with growth in GSP. However, an increase in private union membership within a state results in a (significant) decrease in productivity growth. The chi-square test indicates that the public union and private union coefficients are statistically different in their effects on productivity and GSP growth. In each case, the private union measure is significantly more than the public union coefficient.

TABLE 3

Public and Private Sector Unions and Economic Growth (absolute t-statistics)

\begin{tabular}{lcccc}
\hline Variable & GSP Growth & $\begin{array}{c}\text { GSP Growth } \\
\text { (fixed) }\end{array}$ & $\begin{array}{c}\text { Productivity } \\
\text { Growth }\end{array}$ & $\begin{array}{c}\text { Productivity } \\
\text { Growth (fixed) }\end{array}$ \\
\hline Constant & $3.048^{*}$ & & $1.295^{* * *}$ & \\
& $(3.78)$ & & $(1.73)$ & 0.035 \\
Public union & 0.005 & $0.074^{* * *}$ & 0.006 & $(0.36)$ \\
& $(0.51)$ & $(1.86)$ & $(0.17)$ & 0.037 \\
Public union ${ }^{2}$ & & & 0.012 & $(0.30)$ \\
& & & $(0.28)$ & $-0.535^{*}$ \\
Private union & 0.035 & -0.147 & $-0.185^{* * *}$ & $(2.92)$ \\
& $(1.27)$ & $(1.44)$ & $(1.86)$ & $1.550^{*}$ \\
Private union ${ }^{2}$ & & & $0.625^{* * *}$ & $(2.65)$ \\
GSP/capita & $-1.188^{*}$ & $-7.887^{*}$ & $(1.65)$ & \\
& $(3.51)$ & $(6.78)$ & & \\
Population growth & $1.233^{*}$ & $2.137^{*}$ & & $0.312^{*}$ \\
& $(11.12)$ & $(9.08)$ & & $(3.43)$ \\
\%Manufacturing & $0.074^{*}$ & 0.089 & $0.056^{*}$ & 0.570 \\
& $(3.65)$ & $(0.71)$ & $(3.01)$ & $0.13^{*}$ \\
Public-Private Union & -0.03 & 0.221 & 0.245 & $2.87^{* * *}$ \\
$\chi^{2}$ & $14.36^{*}$ & $5.00^{* *}$ & & \\
\hline
\end{tabular}

***indicates significance at the $10 \%$ level.

** indicates significance at the $5 \%$ level.

* indicates significance at the $1 \%$ level

For private union membership, the second order impact on productivity reveals the limits to these gains in membership. The positive significant coefficient on the squared term for private union membership identifies an optimum level of private unionization with respect to productivity growth.

Solving the local optimum yields that, for private unionization, the initial impact on productivity is negative; however productivity reaches a minimum at a private unionization rate of 17.26 percent. $^{7}$ After that, the second order effect dominates and productivity begins to recover. Interpreting the impact of unionism for rates greater than 17 percent must be done with care. The structure raises the possibility of a bipolar impact of private unionization rates. To enhance productivity, either private unionization should be relatively low or private unions

7The local optimum can be found by taking the partial derivative of the productivity growth equation with respect to public and private unionization, setting equal to zero. 
could grow very large to offset the initial negative effect. Beyond the level of 17.26 percent, the second order effect dominates increasing productivity. A state with unionization levels below this minimum would see productivity enhanced by reducing unionization while those with unionization levels above this threshold may increase productivity by encouraging union membership. However this analysis of productivity and private unionization is limited by the sample used. As shown in Figure 2, only Michigan had a unionism rate greater than 17 percent in 1996 . Thus, little may be deduced about the impact of unionism on productivity if unions were to expand.

The GSP equation reveals a significant negative convergence effect for per capita GSP. The negative significant coefficient on per capita GSP lends evidence in support of a convergence effect for state economic growth. Furthermore, the fixed effects model demonstrates that the coefficient on the convergence variable is enhanced after controlling for fixed effects. The coefficient on manufacturing employment initially appears to suggest a positive relationship between manufacturing and growth in GSP. This coefficient is no longer significant when fixed effects are considered at the state level. Thus, we cannot conclude that increasing employment in the manufacturing sector is a path to higher growth in GSP. Manufacturing employment is a positive significant factor for productivity growth. This is expected and is consistent with the results found for manufacturing employment and wages. The control for population growth yields the expected positive significant coefficient on GSP growth. An increase in the state's population is correlated with growth in GSP. In the fixed effects model, the coefficient on population growth is not only significantly greater than zero, it is also significantly greater than one. Thus, population growth is correlated with a greater than proportional increase in GSP.

\section{CONCLUSION}

This paper has presented an analysis of the difference between public and private union density using U.S. state-level data. There are significant differences between the effects of public and private union density on labor markets and economic growth. Within the labor market, private unionization raises unemployment rates significantly, and significantly more than does public unionism. Neither public unionism nor private unionism is significantly correlated with wage inflation, but private unionization has a significantly greater effect on wage inflation than public unionism.

Manufacturing employment is a significant factor, as the industry mix influences each of the estimation equations. From the fixed effects estimations, the share of manufacturing employment is seen to significantly decrease unemployment rates, increase wage inflation, and increase productivity growth. Manufacturing employment is not a significant factor for GSP growth.

Private unionization is found to decrease productivity growth. However, this growth decrease has an offsetting second order term. Hence, a minimum level of productivity is obtained when the private unionization rate is about 17.26 
percent. Within the sample, most states have declined below this threshold in recent years. Only Michigan remains above this level. Hence, little inference can be drawn as to the potential impact of unionism on productivity at higher rates of unionization. Public unionization does not significantly alter productivity, but has a significantly lower impact on productivity than does private unionization.

This study concludes that aggregating union data to estimate macroeconomic effects masks the impact of public unions on a state's economy. If the trend of public unions gaining in their share of total union membership continues, we may witness a period in which union impacts on state economies exhibit the characteristics of public rather than private unions.

\section{APPENDIX}

\section{Definitions (All data are at the state level.)}

1. UR: the annual unemployment rate.

2. WAGINF: the annual percentage change in the wage.

3. PUBUNION: the percentage of employed workers who are in public unions.

4. PRIUNION: the percentage of employed workers who are in private unions.

5. PROD: the annual percentage change in the ratio of GSP/employment.

6. GSP: the annual percentage change in the gross state product.

7. POP: the annual percentage change in the population.

8. EMP: the annual percentage change in the number of people employed.

8. All lag variables are one-year lags in the respective variable.

9. The regions are $\mathrm{NE}=\mathrm{CT}, \mathrm{ME}, \mathrm{MA}, \mathrm{NH}, \mathrm{RI}, \mathrm{VT} ; \mathrm{MA}=\mathrm{NJ}, \mathrm{NY}, \mathrm{PA}$; WC $=\mathrm{IA}, \mathrm{KS}$, $\mathrm{MN}, \mathrm{MO}, \mathrm{NE}, \mathrm{ND}, \mathrm{SD} ; \mathrm{PC}=\mathrm{CA}, \mathrm{OR}, \mathrm{WA} ; \mathrm{SA}=\mathrm{DE}, \mathrm{FL}, \mathrm{GA}, \mathrm{MD}, \mathrm{NC}, \mathrm{SC}, \mathrm{VA}$, $\mathrm{WV} ; \mathrm{ES}=\mathrm{AL}, \mathrm{KY}, \mathrm{MS}, \mathrm{TN}$; WS = AR, LA, OK, TX; WM = AZ, CO, ID, MT, NV, $\mathrm{NM}, \mathrm{UT}, \mathrm{WY}$. The control region is EN = IL, IN, OH, MI, WI.

\section{Data Sources}

1. Data on employment and unemployment are taken from the U.S. Department of Labor, Bureau of Labor Statistics.

2. Gross state product (GSP) data are from the U.S. Department of Commerce, Bureau of Economic Analysis.

3. Union membership data are from the United States Statistical Abstracts and diskettes from Hirsch and McPherson $(1993,2003)$.

4. Wage data are from the U.S. Department of Labor, Employment and Training Administration.

\section{REFERENCES}

Addison, John T., and Barry T. Hirsch. "Union Effects on Productivity, Profits, and Growth: Has the Long Run Arrived?" Journal of Labor Economics 7 (1) (1989), 72-105. 
Allen, Steven G. "Unions and Job Security in the Public Sector." In R.B. Freeman and C. Ichniowski (eds.) When Public Sector Workers Unionize. Chicago: The University of Chicago Press, 1988.

Babcock, Linda C., and John B. Engberg. "A Dynamic Model of Public Sector Employer Response to Unionization." Journal of Labor Research 18 (2) (Spring 1997), 265-286.

Barro, R.J., and X. Sala-i-Martin. "Convergence across States and Regions." Brookings Papers on Economic Activity 1 (1991), 107-182.

Bartik, T.J. Who Benefits From State and Local Economic Development Policies? Kalamazoo, Mich.: W.E. Upjohn Institute for Employment Research, 1991.

Courant, Paul N., Edward M. Gramlich, and Daniel L. Rubinfeld. "Public Employee Market Power and the Level of Government Spending." American Economic Review 69 (5) (1979), 806-817.

Freeman, Richard B. "Contraction and Expansion: The Divergence of Private Sector and Public Sector Unionism in the United States." Journal of Economic Perspectives 2 (2) (Spring 1988), 63-88.

Freeman, R.B., and J.L. Medoff. What Do Unions Do? New York: Basic Books, 1984.

Freeman, R.B., and R.G. Valetta. "The Public Sector Look of American Unionism." In R.B. Freeman and C. Ichniowski (eds.) When Public Sector Workers Unionize. Chicago: The University of Chicago Press, 1988.

Hirsch, Barry T. "Unionization and Economic Performance, Evidence on Productivity, Profits, Investment, and Growth." In Fazil Mihlar (ed.) Unions and Right-to-Work Laws. Vancouver: Fraser Institute, 1997.

. Labor Unions and the Economic Performance of Firms. Kalamazoo, Mich.: W.E. Upjohn Institute for Employment Research, 1991.

Hirsch, B.T., and A.N. Link. "Unions, Productivity, and Productivity Growth." Journal of Labor Research 5 (1) (1984), 29-37.

Hirsch, Barry T., and David A. Macpherson. "Union Membership and Coverage Database from the Current Population Survey: Note." Industrial and Labor Relations Review 56 (2) (2003), 349-354.

. "Union Membership and Coverage Files from the Current Population Surveys: Note." Industrial and Labor Relations Review 46 (3) (1993), 574-578.

Hyclak, T., and G. Johnes. Wage Flexibility and Unemployment Dynamics in Regional Labor Markets. Kalamazoo, Mich.: W.E. Upjohn Institute for Employment Research, 1992.

Jensen, J. Bradford, Robert H. McGuckin, and Kevin J. Stiroh. "The Impact of Vintage and Survival on Productivity: Evidence from Cohorts of U.S. Manufacturing Plants." Review of Economics and Statistics 83 (2) (2001), 323-332.

Karras, Georgios, and Leonie Stone. "Determinants of the Natural Rate and Persistence of Unemployment: Evidence for a Panel of U.S. States." University of Illinois at Chicago, 1993.

Katz, L. "Efficiency Wage Theories: A Partial Evaluation." In S. Fischer (ed.) NBER Macroeconomics Annual 1986. Cambridge, Mass.: MIT Press, 1986. 
Kennedy, Peter. A Guide to Econometrics. Cambridge, Mass: MIT Press, 1998.

Krugman, Paul. "Can America Stay On Top?" Journal of Economic Perspectives 14 (1) (Winter 2000), 169-176.

Layard, Richard, S. Nickell, and R. Jackman. Unemployment: Macroeconomic Performance and the Labour Market. Oxford: Oxford University Press, 1991.

Lewis, H. Gregg. "Union/Nonunion Wage Gaps in the Public Sector." Journal of Labor Economics 8 (1) (1990, part 2), S260-S328.

Lindbeck, A., and D.J. Snower. The Insider-Outsider Theory of Employment, Interest and Money. Cambridge, Mass.: MIT Press, 1988.

Maki, Dennis R. "The Effects of Unions and Strikes on the Rate of Growth of Total Factor Productivity in Canada." Applied Economics 15 (1) (1983), 29-41.

Okun, A.M. "Potential GNP: Its Measurement and Significance." Proceedings of the Business and Economic Statistics Section of the American Statistical Association, 98-103. Washington, D.C., 1962. Reprinted in J.A. Pechman (ed.) Economics for Policymaking: Selected Essays of Arthur M. Okun. Cambridge, Mass.: MIT Press, 1983.

Pantuosco, Louis J., and Darrell Parker. "Sources of Prevailing Differences in Unemployment Rates for Selected Regional Pairs." The Review of Regional Studies 28 (2) (1998), 35-46.

Pantuosco, Louis J., Darrell Parker, and Gary Stone. "The Effect of Unions on Labor Markets and Economic Growth: An Analysis of State Data." Journal of Labor Research 22 (1) (Winter 2001), 195-205.

Phillips, A.W. "The Relationship between Unemployment and the Rate of Change of Money Wage Rates in the United Kingdom, 1861-1957." Economica 25 (1958), 283-299.

Summers, L. "Why is the Unemployment Rate So Very High near Full Employment?" Brookings Papers on Economic Activity 2 (1986), 339-383.

Topel, Robert H. "Local Labor Markets." Journal of Political Economy 94 (3) (1986, part 2), S111-S143.

Troy, Leo. "Is the United States Unique in the Decline of Private Sector Unionism?" Journal of Labor Research 11 (2) (Spring 1990), 111-143.

Zax, Jeffrey, and Casey Ichniowski. "The Effects of Public Sector Unionism on Pay, Employment, Department Budgets, and Municipal Expenditures." In R.B. Freeman and C. Ichniowski (eds.) When Public Sector Workers Unionize. Chicago: The University of Chicago Press, 1988. 